\title{
Dinamika Kesetiaan Pada Kaum Gay
}

\author{
Putu Hening Wedanthi dan I. G. A. Diah Fridari. \\ Program StudiPsikologi, Fakultas Kedokteran, UniversitasUdayana \\ heningwedanthi@yahoo.com
}

\begin{abstract}
Abstrak
Homoseksual adalah ketertarikan secara perasaan ataupun secara erotik, baik secara predominan atau eksklusif terhadap individu yang memiliki kesamaan jenis kelamin dengan ataupun tanpa melibatkan hubungan fisik, sedangkan gay merupakan istilah untuk menyebutkan lelaki yang menyukai sesama lelaki sebagai partner seksual, serta memiliki ketertarikan baik secara perasaan atau erotik, baik secara dominan maupun eksklusif dan juga dengan ataupun tanpa adanya hubungan fisik (Putri, 2013).

Kesetiaan adalah sebuah bentuk dari tingkah laku yang dilakukan berulang yang akhirnya akan menjadi sebuah sifat yang permanen. Kesetiaan yang ditujukan kepada pasangan juga berarti bahwa individu di dalam hubungan tesebut dapat saling mengandalkan untuk menjaga komitmen bersama yang telah di sepakati, Cloud \& Townsend (dalam Sari, 2008). Tujuan dari penelitian ini adalah untuk mengetahui dinamika kesetiaan pada kaum gay.

Penelitian ini menggunakan metode penelitian kualitatif dengan pendekatan studi kasus untuk mendeskripsikan dinamika kesetiaan yang terjadi pada hubungan kaum homoseksual. Pengumpulan data dalam penelitian ini menggunakan teknik wawancara dan observasi yang dilakukan terhadap 4 orang subjek gay. Analisa data yang digunakan dalam penelitian ini adalah thematic coding, yaitu menggunakan kemampuan peneliti dalam memilih hal-hal yang dianggap penting dalam hasil penelitian, selain itu dalam pembuatan koding, prosedur yang digunakan mengacu pada teori Straud dan Corbin (2003).

Hasil dalam penelitian ini menunjukkan bahwa dalam dunia gay, sebagian besar individu di dalamnya merupakan orang-orang yang menjalankan prinsip hidup bebas, dimana mereka bergaul dan berperilaku bebas tanpa ada aturan yang mengikatnya. Secara garis besar responden dalam ini menyatakan bahwa kesetiaan merupakan hal yang penting dan mutlak ada dalam sebuah hubungan namun tidak semua gay mampu menjalankan komitmen untuk tetap setia.
\end{abstract}

Kata kunci : homoseksual, gay, kesetiaan ,kualitatif, studi kasus

\begin{abstract}
Homosexual is an interest in feeling or in erotic, both are in predominant or exclusiveness against individuals who has a similarity in sexes violent or without involves interaction physical, while gay is term to mention man who likes fellow man as partners sexual, and have interest both in feeling or erotic, both in dominant and exclusive and also with or without any relation physical (Putri, 2013)

Faithfulness is a form of behaviors that performed recurrently that will eventually become a permanent nature. Directed toward your faithfulness also means that individual in relationship was able to rely to keep commitments together, which has agreed by Cloud\&Townsand (in Sari, 2008). The aim of this research is to find out the dynamics of faithfulness to gay.

This research using qualitative methods by case study approach to describe the dynamics of faithfulness in gay relationship. To collecting data in this research used interview technique and used 4 subject. This research used thematic coding for analyzing data.

The result of this study suggest that in a world of a gay, most individuals within it are the people who run the principle of free life, where they hang out and behaving freely without any rules that tie it. Generally the respondents in this study say that faithfulness is crucial and absolutely there are in relationship but not all gay capable of running commitment to remain faithful.
\end{abstract}

Keywords: Homosexual, Gay, Faithfulness, Qualitatife, Case study 


\section{P. H. WEDHANTI DAN I. G. A. D. FRIDARI}

\section{LATAR BELAKANG}

Manusia sebagai makhluk sosial sudah pasti tidak dapat hidup sendiri dan tidak akan pernah lepas dari kebutuhan akan pasangan hidup. Dalam pembahasan mengenai pencarian pasangan hidup, kita akan selalu terkait dengan hal yang disebut dengan kecenderungan seksual atau sering dikenal dengan istilah orientasi seksual. Secara umum orientasi seksual dibagi menjadi 3, antara lain: homoseksual, yaitu ketertarikan seksual terhadap sesama jenis, heteroseksual, yaitu ketertarikan seksual terhadap lawan jenis dan biseksual, yaitu ketertarikan seksual kepada sesama jenis dan lawan jenis (Dermatoto, 2010).

Istilah homoseksual pertama diciptakan pada abad ke-19 oleh seorang psikolog Jerman yaitu Karoly Maria Benkert, Homo berasal dari bahasa Yunani yang berarti sama dan seks berarti jenis kelamin. Istilah ini menunjukkan penyimpangan kebiasaan yang menyukai jenisnya sendiri, misalnya pria menyukai pria atau wanita menyukai wanita (Anonim, 2010).Tingkah laku homoseksual adalah usaha untuk memenuhi kebutuhan normal dalam mendapa'tkan kasih sayang, penerimaan dan identitas melalui keintiman seksual dengan orang yang berjenis kelamin sama (Comiskey, 2012).

Ada dua istilah terdapat pada orang yang mempunyai kecenderungan homoseksual yaitu lesbian dan gay dan istilah ini sangat terkenal di lingkungan masyarakat. Lesbian merupakan istilah yang menggambarkan seorang perempuan yang secara emosi dan fisik tertarik dengan sesama perempuan, sedangkan gay merupakan istilah untuk menyebutkan lelaki yang menyukai sesama lelaki sebagai partner seksual, serta memiliki ketertarikan baik secara perasaan atau erotik, baik secara dominan maupun eksklusif dan juga dengan ataupun tanpa adanya hubungan fisik (Putri, 2013).

Masyarakat sering beranggapan bahwa homoseksual merupakan suatu gangguan jiwa yang menyebabkan penderitanya mengalami penyimpangan perilaku, namun apabila mengacu pada DSM IV (Diagnostic Manual of Mental Disorder yang dibuat oleh APA) homoseksual tidak lagi diklasifikasikan sebagi kelainan jiwa ataupun penyimpangan lainnya karena memang syarat dari sebuah perilaku untuk dapat diklasifikasikan sebagai sebuah gangguan jiwa adalah apabila perilaku tersebut mengganggu kehidupan penderitanya (Nicolosi, 2001).

Dua tahun terakhir, media banyak dikejutkan dengan kasus pembunuhan berantai. Pada kasus pembunuhan berantai, sebenarnya hal ini dapat dilakukan oleh siapa saja, termasuk non gay. Namun kasus yang mencuat di media masa ini terjadi dalam waktu yang berdekatan dan dilakukan oleh kaum gay, dua diantaranya yaitu Ryan dan Mujianto, mereka merupakan orang- orang yang memiliki ketertarikan dengan sesama jenis, dalam hal ini laki- laki yang menyukai sesama laki-laki atau sering kita kenal dengan sebutan "gay".

Pada kasus Ryan, Ryan membunuh korbannya yang bernama Heri Santoso (40), salah satu dari 11 orang korbannya ini adalah seorang manager penjualan sebuah perusaah swasta di Jakarta. Ryan membunuh Heri atas dasar tersinggung karena Heri menawarkan sejumlah uang untuk berhubungan dengan pacar Ryan yang juga seorang laki-laki yang bernama Noval. Pada hasil pemeriksaan kejiwaannya, Ryan dinyatakan tidak mengalami gangguan jiwa namun ia memiliki sifat yang sensitif, mudah tersinggung, impulsif dan agresif (Dede, 2008). Dalam kasus Mujianto, motif pembunuhan terhadap korbannya hampir sama dengan Ryan, yaitu karena rasa cemburu ketika mengetahui bahwa pasangannya yang berinisial JS memilki banyak kekasih (Dede, 2008). Dalam hal ini dapat dilihat bagaimana mereka sangat mempertahankan kesetiaan, dan melakukan apa saja untuk mempertahankan hubungan mereka dengan pasangannya.

Dalam kasus lain, peneliti mendapatkan sebuah fakta melalui wawancara dengan seorang gay. Dari pengalaman masa lalunya yang pernah dikhianati, responden merasa penting untuk menjaga kesetiaan dalam menjalin sebuah hubungan. Dari hasil wawancara tersebut, penulis juga mendapatkan beberapa fakta bahwa bagi responden, kesetiaan merupakan suatu hal yang sangat penting dan merupakan unsur yang mutlak dalam suatu hubungan namun sampai saat ini, responden masih sulit untuk menjaga kesetiaan tersebut.

Menurut Warren (dalam Sari, 2008) Kesetiaan adalah sebuah bentuk dari tingkah laku yang dilakukan berulang yang akhirnya akan menjadi sebuah sifat yang permanen. Kesetiaan yang ditujukan kepada pasangan juga berarti bahwa individu di dalam hubungan tesebut dapat saling mengandalkan untuk menjaga komitmen bersama yang telah di sepakati, Cloud \& Townsend (dalam Sari, 2008).

Menurut Cloud dan Townsend (dalam Sari, 2008) ada beberapa hal yang mempengaruhi kesetiaan, antara lain: Kedewasaan, kedewasaan yang dimaksud adalah saling mencurahkan kasih sayang kepada pasangan, memiliki penghasilan sendiri, jujur, bertanggung jawab, percaya diri, mampu menyelesaikan permasalahan, serta dapat mengetahui potensi dirinya, empati, yaitu mampu melihat suatu permasalahan tidak hanya dari kaca mata diri sendiri tapi juga dari kaca mata pasangan, komitmen yaitu janji untuk melakukan sesuatu yang telah di sepakati bersama, kejujuran, yaitu berkata apa adanya yang harus disertai dengan kelapangan hati dalam mendengar dan menghadapi kenyataan yang terungkap oleh kejujuran tersebut dan yang terakhir adalah pengampunan, yaitu dengan iklas memberikan maaf kepada pasangan yang melakukan kesalahan.

Salah satu bentuk pelanggaran terhadap kesetiaan adalah perselingkuhan. Menurut Subotnik \& Harris, 2005 
(dalam Ginanjar, 2009) ada beberapa bentuk perselingkuhan, antara lain adalah: Serial affair, tipe ini tidak melibatkan emosi atau perasaan namun terjadi berulang kali, tujuan dari hubungan ini adalah untuk mendapatkan kenikmatan seksual melalui seks dan gairah, flirting , tipe ini mirip dengan serial affair yaitu tidak melibatkan perasaan dan hubungan seksual namun hanya terjadi satu kali, Romantic love affair, tipe ini melibatkan hubungan emosional yang mendalam. Seringkali individu berpikir untuk meninggalkan pasangannya demi menjalani hubungan ini, long term affair, tipe ini merupakan jenis perselingkuhan jangka panjang yang melibatkan perasaan emosional yang lebih mendalam dibandingkan dengan romantic love affair. Perselingkuhan ini dapat berlangsung bertahun-tahun.

Dari beberapa kasus di atas, peneliti tertarik untuk melakukan penelitian yang dapat menggali bagaimana dinamika kesetiaan di dalam sebuah hubungan kaum gay.

\section{METODE}

\section{Tipe Penelitian}

Pada penelitian ini, peneliti menggunakan metode penelitian kualitatif. Menurut Strauss dan Corbin (1997), yang dimaksud dengan penelitian kualitatif adalah jenis penelitian yang menghasilkan penemuan-penemuan yang tidak dapat dicapai (diperoleh) dengan menggunakan prosedurprosedur statistik atau cara-cara lain dari kuantifikasi (pengukuran). Penelitian kualitatif secara umum dapat digunakan untuk penelitian tentang kehidupan masyarakat, sejarah, tingkah laku, fungsionalisasi organisasi, aktivitas sosial, dan lain-lain. Salah satu alasan mengapa peneliti menggunakan pendekatan kualitatif dalam penelitian ini adalah karena metode ini dapat digunakan untuk menemukan dan memahami apa yang tersembunyi dibalik fenomena yang terkadang merupakan sesuatu yang sulit untuk dipahami secara memuaskan. Dalam meneliti kehidupan homoseksual, peneliti harus menggali informasi secara mendalam hal ini dikarenakan sulitnya mendapatkan informasi dari responden, selain itu fenomena kaum homoseksual ini masih sulit dipahami oleh masyarakat sehingga diperlukan metode yang dapat menggali informasi secara akurat dan mendalam. Dalam penelitian ini, peneliti terlebih dahulu melakukan penggalian data sebelum melakukan penarikan kesimpulan.

Bogdan dan Taylor (1992) menjelaskan bahwa penelitian kualitatif adalah salah satu prosedur penelitian yang menghasilkan data deskriptif berupa ucapan atau tulisan dan perilaku orang-orang yang diamati. Pendekatan kualitatif diharapkan mampu menghasilkan uraian yang mendalam tentang ucapan, tulisan, dan atau perilaku yang dapat diamati dari suatu individu, kelompok, masyarakat, atau organisasi tertentu dalam suatu seting tertentu yang dikaji dari sudut pandang yang utuh, komprehensif, dan holistik. Penelitian kualitatif bertujuan untuk mendapatkan pemahaman yang sifatnya umum terhadap kenyataan sosial dari perspektif partisipan. Pemahaman tersebut tidak ditentukan terlebih dahulu, tetapi didapat setelah melakukan analisis terhadap kenyataan sosial yang menjadi fokus penelitian. Berdasarkan analisis tersebut kemudian ditarik kesimpulan berupa pemahaman umum yang sifatnya abstrak tentang kenyataankenyataan (Hadjar, 1996 dalam Basrowi dan Sukidin, 2002).

Pendekatan yang digunakan dalam penelitian ini adalah pendekatan studi kasus. Studi kasus adalah metode penelitian yang menjelaskan secara terperinci suatu seting atau suatu subjek tunggal, atau dokumen tunggal atau suatu kasus tertentu (Wahab, 2011).

Dalam penelitian ini, jenis studi kasus yang digunakan adalah studi kasus mendalam. Peneliti menggunakan jenis studi kasus mendalam karena ingin meneliti secara mendalam keunikan dari kasus yang di angkat serta ingin menggali hal-hal mendasar dari kasus-kasus tersebut, selain itu peneliti ingin melihat keunikan dari kasuskasus tersebut tanpa harus di generalisasi.

\section{Unit Analisis}

Unit analisis menurut Spradly ( dalam Sugiyono, 2007) mengacu pada tiga komponen yaitu: Place atau tempat dimana penelitian tersebut berlangsung, Actor atau orang yang terlibat dalam penelitian dan Activity atau kegiatan yang di lakukan dalam situasi sosial yang berlangsung.

Dalam penelitian ini, unit analisis yang digunakan adalah actor, actor yang termasuk dalam penelitian ini adalah peneliti dan responden itu sendiri.

\section{Responden Penelitian}

Dalam penelitian ini responden yang digunakan merupakan responden utama, dimana responden utama (key informan) merupakan mereka yang mengetahui dan memiliki berbagai informasi pokok yang diperlukan dalam penelitian (Suyanto, 2006). Key informan yang peneliti pilih disini adalah kaum gay yang berusia diatas 18 tahun, hal ini melalui pertimbangan dimana ketika seseorang berusia diatas 18 tahun maka ia akan memiliki pemikiran yang lebih matang dan telah mengetahui arah tujuan hidupnya, sehingga dalam menjalin hubungan responden akan memilih pasangan yang tepat dan sesuai untuk dirinya. Selain itu, responden dalam penelitian ini harus berdomisili di Bali, hal ini karena fokus penelitian dari peneliti adalah kaum gay yang berada di Bali, sehingga dapat memudahkan dalam proses penggalian data. Kriteria inklusi dalam penelitian ini adalah usia responden dan tempat domisilinya sedangkan kriteria inklusi dari penelitian ini adalah kewarganegaraan dan asal daerah responden.

Responden dalam penelitian ini dibagi menjadi dua kategori, yaitu kategori pertama merupakan responden yang 


\section{P. H. WEDHANTI DAN I. G. A. D. FRIDARI}

masih menjaga kesetiaannya dan yang kedua merupakan responden yang tidak bisa menjaga kesetiaannya.

Dalam penelitian ini peneliti menggunakan teknik snowball sebagai teknik sampling, hal ini dikarenakan sulitnya mencari responden yang bersedia terbuka tentang orientasi seksualnya, sehingga apabila menggunakan teknik snowball maka akan lebih mudah.

\section{Teknik Penggalian Data}

Dalam penelitian ini responden yang digunakan merupakan responden utama, dimana responden utama (key informan) merupakan mereka yang mengetahui dan memiliki berbagai informasi pokok yang diperlukan dalam penelitian (Suyanto, 2006). Key informan yang peneliti pilih disini adalah kaum gay yang berusia diatas 18 tahun, hal ini melalui pertimbangan dimana ketika seseorang berusia diatas 18 tahun maka ia akan memiliki pemikiran yang lebih matang dan telah mengetahui arah tujuan hidupnya, sehingga dalam menjalin hubungan ia akan memilih pasangan yang tepat dan sesuai untuk dirinya. Selain itu, responden dalam penelitian ini harus berdomisili di Bali, hal ini karena fokus penelitian dari peneliti adalah kaum gay yang berada di Bali, sehingga dapat memudahkan dalam proses penggalian data. Kriteria inklusi dalam penelitian ini adalah usia responden dan tempat domisilinya sedangkan kriteria inklusi dari penelitian ini adalah kewarganegaraan dan asal daerah responden.

Responden dalam penelitian ini di bagi menjadi dua kategori, yaitu kategori pertama merupakan responden yang masih menjaga kesetiaannya dan yang kedua merupakan responden yang tidak bisa menjaga kesetiaannya.

Dalam penelitian ini peneliti menggunakan teknik snowball sebagai teknik sampling, hal ini dikarenakan sulitnya mencari responden yang bersedia terbuka tentang orientasi seksualnya, sehingga apabila menggunakan teknik snowball maka akan lebih mudah.

\section{Teknik Pengorganisasian dan Analisis Data}

Teknik pengorganisasian data yang peneliti gunakan mengacu pada teknik pengorganisasian data oleh Poerwandari (2005), antara lain:

1. Data mentah (hasil rekaman)

2. Data yang sudah diproses sebagiannya ( transkripsi wawancara, catatan refleksi peneliti)

3. Data yang sudah ditandai atau dibubuhi kode-kode spesifik

4. Penjabaran kode-kode dan kategori-kategori secara luas melalui skema

5. Memo dan draft insight untuk analisi data

6. Catatan pencarian dan penemuan, yang disusun untuk memudahkan pencarian berbagai kategori data

7. Display data melalu skema atau jaringan informasi dalam bentuk padat atau esensial
8. Episode analisis (dokumentasi dari langkah-langkah dan proses penelitian)

9. Dokumentasi umum yang kronologis mengenai pengumpulan data dan langkah analisis

10. Daftar indeks dari semua material

11. teks laporan

Teknik analisa data yang akan digunakan dalam penelitian ini adalah analisa deskriptif. Teknik ini memiliki ciri memusatkan perhatian pada masalah-masalah yang ada pada saat penelitian dilakukan atau masalah yang sedang aktual dibahas dalam masyarakat serta menggambarkan faktafakta tentang masalah yang diteliti sesuai dengan keadaan yang sebenarnya, dilengkapi dengan interpretasi rasional yang adekuat.

\section{Teknik Pemantapan Kredibilitas Penelitian}

Dalam penelitian ini, teknik pemantapan kredibilitas dilakukan dengan menggunakan triangulasi data, data tersebut diperoleh langsung melalui teknik wawancara, dan observasi. Selain itu peneliti juga menggunakan triangulasi pengamat, pengamat yang dimaksud adalah dosen pembimbing yang akan ikut serta mengamati hasil data dan memberikan masukan kepada peneliti guna kesempurnaan hasil penelitian.

\section{HASIL PENELITIAN}

\section{A. Kasus 1 \\ 1. Latar belakang}

Kedua responden dalam kasus ini memiliki latar belakang keluarga yang berbeda. Pada responden 2, latar belakang keluarga responden adalah keluarga yang utuh, namun responden cenderung lebih dekat dengan sang ibu karena ayah responden cenderung keras, sedangkan pada responden 4, dalam keluarga intinya, responden merupakan anak tunggal yang memang sejak masa kanak-kanak telah menunjukkan sikap kewanitaan bila di bandingkan dengan teman-temannya yang lain. Dalam keluarga responden memang dari generasi ke generasi selalu ada anggota keluarga yang menjadi seorang homoseksual. Hal ini sesuai dengan penelitian yang dilakukan oleh Kertbeny\&Karl (dalam Putri, 2005) bahwa salah satu penyebab seseorang menjadi homoseksual adalah karena faktor biologis seperti gen yang dibawa sejak lahir.

\section{Cara pandang}

Kaum gay merupakan orang-orang yang gemar berpesta (party people). Kaum gay sering menghabiskan waktu luangnya dengan pergi ke tempat-tempat hiburan dan berpesta sebagai gaya hidup.

Dalam kaitannya dengan pilihan hidup menjadi seorang gay, responden dalam kasus ini menganggap bahwa hal tersebut adalah normal, pandangan tersebut tidak 
sepenuhnya salah karena menurut Bogdan (dalam APA, 2010). syarat dari sebuah perilaku untuk dapat diklasifikasikan sebagai sebuah gangguan jiwa adalah apabila perilaku tersebut mengganggu kehidupan penderitanya

\section{Kesetiaan}

Dalam berhubungan kesetiaan adalah rasa saling percaya dan saling menjaga ego masing-masing. Di dalam menjaga kesetiaan, kepercayaan dan kejujuran adalah hal yang sangat dibutuhkan agar tidak menyakiti perasaan pasangan, hal ini senada dengan hasil penelitian oleh Cloud dan Townsend (dalam Sari, 2008) yang menyatakan bahwa kejujuran merupakan bagian dari kedewasaan yang sangat berpengaruh terhadap kesetiaan.

Dalam dunia gay, kesetiaan merupakan hal yang sulit untuk dibuktikan, terkadang orang terdekat juga dapat menjadi orang ketiga dalam hubungan yang sedang dijalani oleh kaum gay, selain itu dalam hubungan gay sangat jarang ditemukan orang yang mampu setia hanya pada satu pasangan. Dalam kasus ini, responden hanya pernah menjalin hubungan dengan satu orang laki-laki dan pada akhirnya laki-laki tersebut berselingkuh dengan teman baiknya. Kejadian tersebut membuat responden sakit hati dan sangat selektif dalam memilih pasangan. Meskipun sulit untuk di buktikan dan sulit untuk di jaga, namun apabila satu sama lain dapat secara kooperatif menjaga komitmen bersama, maka menjaga kesetiaan pasti bisa di lakukan, Cloud \& Townsend (dalam Sari, 2008).

\section{Dinamika hubungan}

Awal mula responden 2 menjadi seorang gay terjadi ketika hubungan responden dengan seorang wanita berakhir, setelah itu responden sempat mengikuti tradisi india untuk menjalani perjodohan, namun perjodohan tersebut juga kandas di tengah jalan. Tanpa disengaja responden masuk kedalam group gay yang terdapat di facebook, yang membuatnya kemudian menjadi seorang gay. Jadi, penyebab responden menjadi seorang gay adalah karena faktor lingkungan, dalam hal ini lingkungan yang dimaksud adalah jejaring sosial yang memperkenalkan responden dengan lingkungan gay. Hal ini sesuai dengan teori Kertbeny\&Karl (dalam Putri, 2005) bahwa faktor penyebab seseorang menjadi homoseksual antara lain adalah karena faktor lingkungan yang memberikannya pengalaman mengenai dunia homoseksual.

Dalam proses hubungan yang dijalani, responden sering disakiti oleh pasangannya yang kerap kali berselingkuh di belakang responden. Responden sempat memberi kesempatan kedua untuk pasangannya tersebut namun pasangan responden kembali mengulang kesalahan-kesalahan lama yang tidak dapat diterima oleh responden. Menurut teori dari Subotnik \& Harris (dalam Ginanjar, 2009) dan Responden juga telah memberi pengampunan terhadap pasangannya sesuai dengan teori Cloud dan Townsend (dalam Sari, 2008), pada saat memberi kesempatan ini, responden berada pada tahap penerimaan, namun apabila hanya 1 orang yang ingin memperbaiki hubungan maka hal tersebut tidak rasional dan tidak akan berdampak baik terhadap hubungan sehingga kejadian selingkuh akan terus berulang.

Pada responden 4, awal mula responden menjalin hubungan dengan pasangannya saat ini adalah ketika responden baru tamat SMA. Saat ini responden dan pasangannya menjalani long distance relationship atau hubungan jarak jauh. Responden memberikan kepercayaan penuh kepada pasangannya, meskipun responden tahu bahwa memegang komitmen untuk setia itu merupakan hal yang tidak mudah, terlebih lagi responden sangat memahami sifat pasangannya. Yang bisa responden lakukan saat ini hanyalah menjaga komitmen untuk dirinya sendiri karena ia menganggap bahwa sebuah komitmen berbeda dengan janji, janji bisa saja dilanggar namun komitmen itu harus dijaga karena merupakan kesepakatan antara dua belah pihak, hal ini berarti apa yang dilakukan oleh responden sesuai dengan teori Cloud dan Townsend (dalam Sari, 2008) mengenai komitmen dalam kesetiaan. Karena itulah hubungan responden dan pasangannya sampai saat ini masih bertahan walaupun berada di kota yang berbeda.

B. Kasus 2

a) Latar belakang

Latar belakang keluarga pada responden 1 tidak begitu baik. Ayah dan ibu responden telah bercerai, dan sejak perceraian tersebut responden diasuh oleh neneknya. Responden sejak kecil telah menunjukkan sisi kewanitaannya, responden lebih senang memainkan permainan anak perempuan dibandingkan permainan anak laki-laki. Hal ini dapat dijelaskan oleh teori Kertbeny\&Karl (dalam Putri, 2005) yang menyatakan bahwa apabila anak laki-laki bersifat feminism, sering menggunakan pakaian wanita, bermain boneka, tidak menyukai kekerasan, memiliki keinginan menjadi wanita dan tidak memiliki keinginan untuk dapat menjadi seperti ayahnya maka tiga perempat dari anak-anak seperti ini akan tumbuh menjadi seorang homoseksual.

Latar belakang Responden 3 berasal dari keluarga yang normal, apabila dilihat dari masa kecil responden yang berjalan dengan wajar, penyebab responden menjadi seorang gay tidak dapat dijelaskan dengan melihat pola asuhnya, namun menurut Kertbeny\&Karl (dalam Putri, 2005) apabila dilihat secara psikologis, suatu perilaku berkembang lebih pada dorongan lingkungan sosial dibandingkan dari faktor pola asuh dan genetis.

\section{b) Cara pandang}

Kaum gay memiliki kepercayaan diri yang tinggi, terutama dalam menilai bagaimana orang lain memandang dirinya, hal itulah yang menyebabkan responden berani menyimpulkan bahwa salah satu mantan pacarnya sangat 


\section{P. H. WEDHANTI DAN I. G. A. D. FRIDARI}

terobsesi terhadap dirinya. Rasa percaya diri pada homoseksual sebenarnya memegang peranan penting dalam kehidupan sosialnya karena hal ini dapat membantu relasi dari hubungan sosialnya (Astarina, 2009).

Dalam dunia gay, sangat sulit untuk menemukan pasangan yang mampu bertahan dalam jangka waktu yang panjang, hal ini dipengaruhi oleh lingkungan gay itu sendiri yang tergolong bebas dan tanpa ikatan. Ketika menjalin suatu hubungan, kadang kala seorang gay tidak harus selingkuh atau menjalin hubungan lain diluar hubungan resmi mereka, tapi bisa saja seorang gay melakukan hubungan seksual dengan orang lain yang baru dikenalnya, setelah hubungan itu berakhir, mereka tidak akan merasa saling mengenal lagi, hal ini dikenal dengan istilah one night stand, hal ini sangat bertentangan dengan teori Dianne Hubbard (2003) yang menyatakan bahwa kesetiaan merupakan hubungan intim yang terjalin hanya oleh dua orang, dua orang tersebut kemudian saling berkomitmen dan tidak akan terlibat dalam hubugan seksual dengan orang lain.

c) Kesetiaan

Responden 1 memandang arti dari sebuah kesetiaan adalah suatu hal yang mutlak ada dan merupakan hal yang sangat penting dalam suatu hubungan. Sebelum menjadi seorang homoseksual, responden pernah menjalin hubungan dengan seorang perempuan. Setelah beberapa lama berhubungan, akhirnya responden mengetahui bahwa perempuan tersebut berselingkuh dengan orang lain. Hal tersebut tidak membuat responden trauma, karena pada dasarnya responden lebih tertarik kepada laki-laki.

Kesetiaan merupakan hal yang penting, namun tidak dapat dipungkiri bahwa terkadang seseorang khususnya kaum gay melanggar kesetiaan itu dan memiliki pasangan lebih dari satu orang. Dalam kasus ini,responden merupakan sosok gay yang mementingkan kesetiaan dan pada saat awal menjalin hubungan responden mencoba untuk setia, namun ternyata pasangannya yang melanggar kesetiaan tersebut. Hal ini menyebabkan responden kecewa dan akhirnya banyak menjalin hubungan tanpa status dan kerap kali berganti-ganti pasangan, namun sebenarnya apabila responden benar-benar ingin mempertahankan kesetiaan maka responden harus memberikan pengampunan kepada pasangannya yang melakukan kesalahan sesuai dengan Cloud \& Towned (dalam Sari, 2008).

Selain pengalaman yang responden alami pada saat pasangannya selingkuh dengan orang lain, responden juga pernah menjalin hubungan diluar hubungan resmi yang ia jalani. Hal ini dikarenakan rasa bosan terhadap pasangan yang sama, selain itu alasan responden berselingkuh adalah karena responden merasa rasa cinta yang dimiliki untuk pasangannya tidak cukup kuat yang disebabkan oleh ketidakmampuan responden untuk terus mentolerir kebiasaan-kebiasaan buruk pasangannya. Hal ini tidak sesuai dengan pernyataan Dianne
Hubbard (2003) bahwa dalam suatu hubungan yang menginginkan kesetiaan, hubungan tersebut hanya boleh dijalani oleh dua orang yang saling berkomitmen satu sama lain.

Hubungan gay yang terjalin secara resmi oleh responden sekitar 5 orang, jumlah ini diluar hubungan yang tidak resmi yang responden jalani. Hubungan yang berjalan paling lama yang pernah ia jalani adalah selama 2 tahun.

Responden 3 berpendapat bahwa kesetiaan merupakan komitmen bersama yang terjalin antar manusia yang menjalin hubungan asmara, dimana dalam hal ini kesetiaan tersebut ditunjukkan dengan cara tidak menjalin hubungan dengan orang lain diluar konteks hubungan yang mereka bina, hal ini sama dengan penelitian yang di lakukan oleh Dianne Hubbard (2003) yang menyatakan bahwa kesetiaan merupakan hubungan intim dari dua orang yang saling berkomitmen dan tidak terlibat hubungan dengan orang lain. Meskipun kesetiaan itu merupakan hal yang penting, tapi responden tidak dapat menjaganya.

Hubungan gay terlama yang responden jalani adalah 1tahun 2 bulan dengan pasangan gay ketiganya. Selama menjadi seorang gay responden pernah 5 kali menjalin hubungan.

\section{d) Dinamika hubungan}

Dalam menjalin hubungan, responden lebih berperan sebagai wanita, responden yang mengurusi segala kebutuhan pasangannya. Responden dan pasangannya hidup dengan mengandalkan uang warisan yang dimiliki oleh pasangannya, pasangan responden bertanggung jawab penuh atas diri responden. Ketika menjalin hubungan dengan pasangannya responden tidak mendapatkan restu dari keluarga pasangannya karena responden dianggap memanfaatkan harta pasangannya, sehingga semua uang dalam tabungan pasangan responden diblokir, mereka hidup mengandalkan uang tabungan responden. Namun responden pernah berselingkuh ketika menjalani hubungan ini karena responden tidak mampu untuk mentolerir segala kebiasaan buruk pasangannya. Hubungan responden dan pasangannya ini berakhir secara baik-baik karena pasangan responden memutuskan untuk kembali ke daerah asalnya di Yogyakarta. Dari fakta tersebut atas, responden tergolong dalam jenis homoseksual tulen dimana homoseksual tulen memenuhi gambaran stereotipik lelaki yang memiliki sifat kewanitaan (Coleman, Butcher \& Carson, 1999).

Responden 3 mengawali hubungan dengan pasangannya saat ini ketika responden masih bergelut di dunia modeling. Saat itu pasangan responden memberikan perhatiaan lebih selayaknya anak, hal ini dikarenakan rentang usia mereka yang cukup jauh. Setelah beberapa waktu berjalan akhirnya hubungan responden mengalir begitu saja dan sampai 
saat ini masih menjalin hubungan. Salah satu pemicu responden menjadi seorang homoseksual berkaitan dengan teori Kertbeny dan Karl (2005) yang menyatakan bahwa seseorang dapat menjadi seorang homoseksual diakibatkan oleh faktor lingkungan sekitarnya

\section{PEMBAHASAN DAN KESIMPULAN}

Kaum gay merupakan bagian dari masyarakat yang memiliki hak dan kewajiban yang sama, baik dalam hukum maupun pemerintahan. Kaum gay merupakan komunitas sosial yang di dalamnya terjadi interaksi antara individu satu dengan individu lain. Di dalam interaksi sosial terjadilah kerja sama, persaingan dan pertentangan. Apa bila individu dalam kelompok ini mampu mempertahankan kerja sama yang baik, maka komitmen bersama yang merupakan aspek penting untuk menjaga kesetiaan akan tercapai, namun sebaliknya apa bila yang mendominasi adalah persaingan dan pertentangan, maka yang terjadi adalah perilaku-perilaku negatif yang dapat mengarah kepada tindak kriminal sebagai mana yang terjadi pada kasus Ryan Jombang dan Mujianto.

Pada kasus 1 dan kasus 2, masing-masing responden di dalamnya berasal dari latar belakang yang beragam, responden 1 dan 4 berasal dari keluarga broken home dan responden 2 dan 3 berasal dari keluarga yang utuh. Masingmasing individu dalam tiap kasus juga memiliki cara pandang sendiri tentang dirinya maupun tentang homoseksual, dalam kaitannya tentang kesetiaan, tiap-tiap responden mempunyai cerita dan pengalaman masing-masing, akan tetapi antara kasus 1 dan kasus 2 terdapat persamaan yang signifikan yaitu sama-sama menganggap penting arti kesetiaan dalam hubungan dan menganggap bahwa kesetiaan merupakan hal yang mutlak dalam sebuah hubungan.

Maka dari itu dapat disimpulkan bahwa semua responden pada kasus 1 maupun kasus 2 mengakui bahwa kesetiaan memang penting dalam sebuah hubungan, namun yang membedakan antara kasus 1 dan kasus 2 adalah pilihan hidup dari responden itu sendiri. Pada kasus 1 responden didalamnya merasakan bahwa kesetiaan itu merupakan hal yang sulit namun mereka tetap mempertahankannya dan menjaga komitmen yang telah disepakati bersama pasangannya, sedangkan pada kasus 2 responden di dalamnya memilih untuk mengabaikan kesetiaan yang mereka anggap penting dalam hubungan.

\section{Saran}

1. Saran untuk kaum gay

1. Gay bukan merupakan kelainan jiwa atau kutukan dari Tuhan, gay atau homoseksual merupakan orientasi seksual seorang individu yang patut untuk dihargai, sehingga kaum gay tidak perlu rendah diri akan keadaan mereka.
2. Kaum gay harus menyadari bahwa apapun yang terjadi pada hidup merekamerupakan anugerah dari Tuhan yang patut untuk disyukuri.

3. Kaum gay harus meningkatkan kesadaran diri akan pentingnya kesetiaan yang dapat menghindarkan kaum gay dari pandangan negatif lingkungan dan masyarakat.

\section{Saran untuk masyarakat luas}

1. Jangan memandang sebelah mata pada kaum gay karena kaum gay juga adalah bagian dari masyarakat yang harus dihargai.

2. Tidak semua gay berganti-ganti pasangan, jadi akan lebih bijaksana apabila kita menilai seseorang tidak hanya dari orientasi seksualnya semata namun lebih kepada kepribadiannya sebagai seorang individu.

3. Saran untuk peneliti selanjutnya

1. Bagi peneliti selanjutnya, agar membangun rapor yang baik dengan responden sehingga responden dapat lebih nyaman dan terbuka dalam berbagi informasi mengenai kehidupan gay

2. Membuat kategori-kategori yang jelas sehingga lebih mudah dalam mengelompokkan responden ke dalam kategori tersebut

3. Mencari literatur sebanyak-banyaknya terkait dengan penelitian.

\section{DAFTAR PUSTAKA}

Anonim. (2006, July). Faithfulness in marriage. Diunduh tanggal 12 Oktober 2012 dari http://www.medicalteams.org/docs/learningzone/Faithfulness in Marriage. pdf?sfvrsn=0

Anonim. (2010). Sejarah homoseksual. Diunduh tanggal 1 Oktober 2013 dari http://homseks.blogspot.com/2010/08/sejarahhomoseksual.html

Anonim. (2011). Inilah sejarah waria dan homo. Diunduh tanggal 1 Oktober 2011 dari http://www.artikelbagus.com/2011/09/inilahsejarah-waria-dan-homo.html

APA. (2008). Answer to your question: For a better understanding of sexual orientation and homosexuality. Diunduh tanggal $12 \quad$ Oktober 2012, dari http://www.apa.org/topics/sorientation.pdf

Astarina. (2009). Hubungan antara kepercayaan diri dengan perilaku agresi pada homoseksual di kota malang. Diunduh tanggal 25 September 2013 dari http://library.um.ac.id/freecontents/index.php/pub/detail/hubungan-antara-kepercayaandiri-dengan-perilaku-agresi-pada-homoseksual-di-kota-malangmula-wahyu-erma-astarina-41696.html 


\section{P. H. WEDHANTI DAN I. G. A. D. FRIDARI}

Burton, S. (2000). The causes homosexuality: What science tell us. Diunduh tanggal 25 September 2013 dari http://www.jubileecentre.org/uploaded/files/resource_292.pdf

Buss, D.M \& Schackelford. (1997). Susceptibility to infidelity in the first year of marriage. Diunduh tanggal 15 Februari 2013, dari http://homepage.psy.utexas.edu/homepage/group/busslab/pdffile s/susceptibility\%20to\%20infidelity-jrp-1997.pdf

Comiskey, A. (2012). Apakah homoseksual itu?. Diunduh tanggal 1 Oktober $2013 \quad$ dari http://www.pancarananugerah.org/index.php?option=com_conte nt\&view=article \&id=21:apakah-homoseksual-itu\&catid=24:homoseksualitas

Danandjaja, J. (1979). Diskriminasi terhadap minoritas masih merupakan masalah actual di Indonesia sehingga masih perlu ditanggulangi segera. Diunduh tanggal 1 Oktober 2013 dari http://www.lfip.org/english/pdf/bali-

seminar/Diskriminasi\%20terhadap\%20minoritas\%20-

$\% 20$ james\%20danandjaja.pdf

Dede, W. (2008). Pembunuhan berantai ala ryan jomban.Diunduh tanggal $\quad 1 \quad$ Oktober 2008 dari http://windede.com/2008/08/02/pembunuhan-berantai-ala-ryanjombang/

Demartoto, Argyp. (2002). Mengerti, memahami dan menerima fenomena homoseksual. Diunduh tanggal 12 Oktober 2012, dari http://argyo.staff.uns.ac.id/files/2010/08/seksualitas-undip.pdf

Dermatoto, A. (2010). Seks,gender dan seksualitas lesbian.Diunduh tanggal $\quad 1 \quad$ Oktober $2013 \quad$ dari http://argyo.staff.uns.ac.id/files/2010/08/seks-gender-danseksualitas.pdf

Diputra, H. (2012).Dinamika psikologis pada gay yang menjalin hubungan heteroseks. Diunduh tanggal 1 Oktober 2013 dari http://mevoiceforu-

mevoiceforu.blogspot.com/2012/02/dinamika-psikologis-padagay-yang.html

Eastman, E.D. (1990). Homosexuality; Not a sin, not a sickness. Diunduh tanggal 25 September 2013 dari http://mccchurch.org/?wpfb_dl=4

Fransisca, M. (2009). Gambaran psychological well being. Diunduh tanggal 23 Februari 2013, dari http://lontar.ui.ac.id/file?file=digital/125405-

$155.5 \% 20 \% 20 \mathrm{MAY} \% 20 \mathrm{~g} \% 20 \% 20 \mathrm{Gambaran} \% 20$ psychological $\% 20 \% 20$ Pendahuluan.pdf

Ginanjar, A.S. (2009). Proses healing pada istri yang mengalami perselingkuhan suami. Diunduh tanggal 1 Oktober 2013 dari http://repository.ui.ac.id/dokumen/lihat/5636.pdf

Ginintasari, R. (2012). Kelompok sosial. Diunduh tanggal 1 Oktober 2013

dari
http://file.upi.edu/Direktori/FIP/JUR.._PSIKOLOGI/195009011 981032-

RAHAYU_GININTASARI/Kelompok_Sosial_\%255BCompati bility_Mode\%255D.pdf

Handoyo, A.H. (2002). Aktivitas komunikasi dan pembentukan realitas sosial: satu telaah tentang bagaimana kelompok "gay" melalui aktivitas komunikasi mengonstruksikan homoseksualtas sebagai realitas social (Disertasi). Penerbit FISIP UI. Jakarta. 2002. (Serial Online) diakses melalui http://www.digilib.ui.ac.id/Lontar

Haryanto. (2011). Bentuk-bentuk interaksi sosial.Diunduh tanggal 29 September 2013 dari http://belajarpsikologi.com/bentuk-bentukinteraksi-sosial/

Hubbard, D. (2003). Faithfulness, adultery and the law. Diunduh tanggal $25 \quad$ Oktober 2012, dari http://www.lac.org.na/projects/grap/Pdf/adultery.pdf

Kirkpatrick, R.C. (2000). The evolution of homosexual behavior. Diunduh tanggal 15 Agustus 2013 dari http://www.fed.cuhk.edu.hk/ lchang/material/Evolutionary/evo $\% 20$ homosexual\%20review.pdf

Lembaga Iqama Malang. (2007). Kajian ilmiah penyebab homoseks. Diakses dari http://www.iqama.org/index2.php?option=comcontents\&dopdf= $1 \& \mathrm{id}=681$

Liliana, Vidia. (2009). Komunikasi interpersonal "gay". Diunduh tanggal $25 \quad$ September $2013 \quad$ dari http://skripsi.umm.ac.id/files/disk1/348/jiptummpp-gdl-s1-2009vidialilia-17382-PENDAHUL-N.pdf

Meeza, W. \& Rauch, J. (2005) Gay marriage, same-sex parenting an america's children. Diunduh tanggal 15 Februari 2013. dari http://futureofchildren.org/futureofchildren/publications/docs/15 _02_06.pdf

Moleong \& Lexy, J. 2004. Metodologi penelitian kualitatif.Edisi Revisi. Bandung: PT Remaja Rosdakarya Bandung

Nicolosi, Joseph. (2001). The removal of homosexuality from the psychiatric manual. Diunduh tanggal 25 September 2013 dari http://cssronline.org/CSSR/Archival/2001/Nicolosi_71-78.pdf

Nugroho, S.C, Siswati, Sakti, H. (2012). Pengambilan keputusan menjadi homoseksual pada laki-laki usia dewasa awal. Diunduh 16 Agustus 2013, dari http://eprints.undip.ac.id/11145/1/Jurnal__Sigit_Cahyo_N_-_M2A005074.pdf

Zuhra, W.U.N. (2012). Citra homoseksual dalam media massa online nasional. Diunduh tanggal 20 Oktober 2012, dari http://www.jurnal.usu.ac.id/index.php/flow/article/.../1598/910

Okdinata. (2009). Religiusitas kaum homoseks. Skripsi. Yogyakarta. Fakultas Ilmu Sosial dan Humaniora Universitas Islam Negeri Sunan Kalijaga Yogyakarta. Diunduh tanggal 1 Oktober 2013 


\section{DINAMIKA KESETIAAN PADA KAUM GAY}

dari http://digilib.uinsuka.ac.id/3693/1/BAB\%20I,\%20IV,\%20DAFTAR\%20PUSTA KA.pdf

Pangaribuan, T.R. (2012). Hubungan variasi bahasa dengan kelompok sosial dan pemakaian bahasa. Diunduh tanggal 1 Oktober 2013 dari http://digilib.unimed.ac.id/public/UNIMEDArticle-23425-Tangson\%20R.\%20Pangaribuan.pdf

Pradana, M.I. (2009). Interaksi sosial pada anak periode late childhood yang bekerja. Diunduh tanggal 1 Oktober 2013 dari http://www.gunadarma.ac.id/library/articles/graduate/psycholog y/2009/Artikel_10504114.pdf

Pratiwi, Sudadi \& Yasin. (2013). Pengaruh solidaritas kelompok sosial terhadap perilaku agresi siswa kelas XI SMA negeri 85 Jakarta. Diunduh tanggal 1 oktober 2013 dari http://skripsippknunj.com/wpcontent/uploads/2013/06/Pengaruh-Solidaritas-KelompokSosial-terhadap-Perilaku-Agresi-Siswa-Kelas-XI-SMA-Negeri85-Jakarta1.pdf (Tiara Cita Okta Pratiwi, 2013)

Putri, S.K. (2008). Proses coming out pada gay. Diunduh tanggal 15 Februari 2013, dari http://www.gunadarma.ac.id/library/articles/graduate/psycholog y/2007/Artikel_10502236.pdf

Reksodirdjo, W.A. (2012). Homoseksualitas di indonesia: Antara kenyataan dan hipokritas. Diunduh tanggal 23 Februari 2013, dari https://icssis.files.wordpress.com/2012/05/1819072011_32.pdf Sa'adah, U.L. (2008). Pembentukan identitas seksual kaum gay. Skripsi. Universitas Islam Negeri (UIN) Malang. Diunduh tanggal $25 \quad$ September $2013 \quad$ dari http://lib.uinmalang.ac.id/?mod=th_viewer\&page=2\&id=fullcha pter/04410038.pdf

Sabtono, P.H. (2012). Kehidupan sosial manusia. Diunduh tanggal 1 Oktober $2013 \quad$ dari http://abelpetrus.files.wordpress.com/2012/10/kehidupan-sosialmanusia.pdf

Sari, A.E. (2008). Faktor-faktor yang Mempengaruhi Kesetiaan dalam Perkawinan.Skripsi. Semarang. Fakultas Psikologi Universitas Katolik Soegijapranata. Diunduh tanggal 15 Februari 2013. dari http://eprints.unika.ac.id/1772/1/02.40.0182_Artista_Ema_Sari.p df

Schmitt, D.P, Buss, D.M. (2000). Sexual dimensions of person description: Beyond or subsumed by the big five?. Diunduh tanggal $16 \quad$ Agustus 2013, dari http://www.homepage.psy.utexas.edu/homepage/group/busslab/ pdffiles/sexual\%20dimensions-2000-jrp.pdf

Somantri, G.R. (2005). Memahami metode kualitatif. Diunduh tanggal $29 \quad$ September 2013 dari http://repository.ui.ac.id/contents/koleksi/2/079042802a3318ff6 e3229371985f40e03564492.pdf

Wahab, R. (2011). Mengenal studi kasus. Diunduh tanggal 29 September 2013 dari http://staff.uny.ac.id/sites/default/files/pendidikan/Rochmat $\% 20$ Wahab,\%20M.Pd.,MA.\%20Dr.\%20,\%20Prof.\%20/Case\%20Stu dies.pdf

Yaconis, M.A. (2012). Marriage-selfless sexual faithfulness. Diunduh tanggal 15 Agustus 2013, dari http://him.org/gladtidings/articles/Marriage:_Selfless_Sexual_F aithfulness_issue_92.pdf

Yin, R.K. (2002). Studi kasus, desain dan metode. Jakarta: Raja Grafindo Persada 